\title{
Multi-perspective views on the educational practice of Pestalozzi's institute in Yverdon: the correspondence of the Lejeune brothers
}

\author{
Horlacher, Rebekka
}

\begin{abstract}
This article reconstructs the educational world from the perspective of a child. The sources are over one hundred letters written by Eduard Lejeune, son of a medical doctor in Frankfurt, during his three-year stay in Pestalozzi's famous institute in Yverdon. The letters provide us with weekly reports about the young student's perspective of living and studying in Yverdon, they give an account of his view on his younger brother Gustav, who joined the institute as well, but also on friends, teachers, classes, illnesses and trips. The paper aims to reconstruct the meaning of education in Pestalozzi's institute through the perspective of Eduard and to discuss the different significance attributed to education by the adults, e. g., Pestalozzi and his team, and the way it was perceived by the pupil, Eduard. This comparison is possible since the boys' tutor, Elias Mieg, also regularly informed the parents about the progress of their sons and serves as a third voice in this reconstruction.
\end{abstract}

DOI: https://doi.org/10.24894/2673-4419.00117

Posted at the Zurich Open Repository and Archive, University of Zurich

ZORA URL: https://doi.org/10.5167/uzh-211816

Journal Article

Published Version

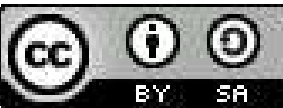

The following work is licensed under a Creative Commons: Attribution-ShareAlike 4.0 International (CC BY-SA 4.0) License.

Originally published at:

Horlacher, Rebekka (2021). Multi-perspective views on the educational practice of Pestalozzi's institute in Yverdon: the correspondence of the Lejeune brothers. XVIII.ch, 2021(12):89-102.

DOI: https://doi.org/10.24894/2673-4419.00117 


\title{
Multi-perspective views on the educational practice of Pestalozzi's institute in Yverdon: the correspondence of the Lejeune brothers
}

Rebekka Horlacher

\begin{abstract}
This article reconstructs the educational world from the perspective of a child. The sources are over one hundred letters written by Eduard Lejeune, son of a medical doctor in Frankfurt, during his three-year stay in Pestalozzi's famous institute in Yverdon. The letters provide us with weekly reports about the young student's perspective of living and studying in Yverdon, they give an account of his view on his younger brother Gustav, who joined the institute as well, but also on friends, teachers, classes, illnesses and trips. The paper aims to reconstruct the meaning of education in Pestalozzi's institute through the perspective of Eduard and to discuss the different significance attributed to education by the adults, e.g., Pestalozzi and his team, and the way it was perceived by the pupil, Eduard. This comparison is possible since the boys' tutor, Elias Mieg, also regularly informed the parents about the progress of their sons and serves as a third voice in this reconstruction.
\end{abstract}

Keywords: education; schooling; children; upbringing; egodocuments; Johann Heinrich Pestalozzi

In summer 1806, the physician Franz Adam Lejeune travelled from Frankfurt to Switzerland to visit Johann Heinrich Pestalozzi's institute in Yverdon. Lejeune was just one of many visitors who made the journey to Yverdon, eager to see one of the most famous educational sites of the early nineteenth century. In Lejeune's case, the visit to Yverdon had a particular goal, as he planned to enrol his two sons, August Eduard and Johann Gustav Adolf, then nine and six years old, at the institute. Upon his arrival in Yverdon, he was personally welcomed by Pestalozzi and introduced to the staff, and Lejeune even sat in on several classes, which he found inspiring. «It's just incredible, inconceivable! The astuteness and understanding of these six- to eight-year old children is simply humbling. I can't make any judgment yet; I'm just marvelling and amazed.» ${ }^{1}$ Yet Lejeune's interest in the institute extended beyond educational methods and pedagogical settings. He also made numerous observations about the structural quality of the buildings and - as he was a medical doctor - the children's physical and psychological health. He was glad to report that the beds in the children's rooms were "very clean» and that he had found «no real untidiness». He also remarked positively on the leisure activities at the institute; the children were engaged in a

1 Eduard Platzhoff-Lejeune, «Ein Besuch bei Pestalozzi in Yverdon im Jahre 1806», Schweizerische Lehrerinnen-Zeitung 31, 1926, no. 3, p. 33-35; no. 4, p. 49-51; no. 5, p. 67-69, here p. 49. 
broad range of activities, from copying maps and setting up herbaria to playing loudly in the courtyard and singing to the accompaniment of violin and cello ${ }^{2}$. What he saw confirmed Lejeune's intention to send his two sons to Yverdon for their schooling, since the advantages would thoroughly outweigh disadvantages such as the "teachers' lousy Swiss German», their "unpleasant and faulty pronunciation" or the "jamming together of too many children in the bedrooms and a certain lack of cleanliness $»^{3}$.

About one year later, at the beginning of August 1807, the two boys, accompanied by their private tutor Johann Elias Mieg, arrived in Yverdon, where the elder was to spend a total of four years and the younger around three years. During their stay in Yverdon, the boys regularly sent letters home ${ }^{4}$; these letters were occasionally supplemented by longer reports from their tutor Mieg. This collection of more than one hundred letters - the majority from the older brother Eduard - are proper «egodocuments $»^{\mathbf{5}}$ or «first-person writing", as they document the children's view of their life in Yverdon and offer insights into dayto-day life at a boarding school at the beginning of the nineteenth century. In particular, they provide information about the institute's practices of education and pedagogy as seen from the perspective of the children ${ }^{6}$. The paper analyzes the educational practices in an early-nineteenth-century boarding school and contrasts them with the aims and intentions of this school as presented in the official and programmatic writings. In doing so, the historiographical added value of this kind of egodocuments are discussed as well.

Even if these letters can obviously be subsumed under the term «egodocuments", they do not reflect the I or the self of the writer, they hardly reflect his

4 In the first months, the Lejeune brothers sent a letter home once a week, and the parents replied regularly. Over time, the frequency dropped to two to three letters a month. From the final phase of the older brother's stay in Yverdon only a few letters are extant.

5 For the methodological discussions on egodocuments see, for example, Claudia Ulbrich, Kaspar von Greyerz, Lorenz Heiligensetzer (eds.), Mapping the 〈I〉. Research on Self-Narratives in Germany and Switzerland, Leiden, Brill, 2015 or Danièle Tosato-Rigo (ed.), Appel à témoins. Ecrits personnels et pratiques socioculturelles ( $X V I^{e}-X X^{e}$ s.), Lausanne, Université de Lausanne, 2016. I'm using the term in a broad sense for non-public and non-official sources. As Danièle Tosato-Rigo has convincingly argued, egodocuments are specifically useful for educational history, as they offer insights into domestic contexts and enable us - in particular for the eighteenth century - to reconstruct the role of non-institutional, often female actors within educational history (Danièle TosatoRigo, «Paroles de témoins: Vers une pluralisation du récit historique», Encounters/Encuentros/Rencontres on Education 15, 2014, p. 137-159, here p. 139-142).

6 Regarding the source material, a problematic aspect is that it is occasionally tendentious, as many remarks clearly seek to please the reader (i.e., the father). However, the letters nevertheless enable a specific view of the institutional life in Yverdon, since they permit us to reconstruct the educational practice based on other sources than Pestalozzi's own programmatic writings or the admiring or critical reports of visitors (see, e.g., Anton Gruner, Briefe aus Burgdorf, über Pestalozzi, seine Methode und Anstalt, Hamburg, Friedrich Perthes Buchhandlung, 1804). 
intellectual or emotional behaviour, and are not useful to construe a subject or persona. They are just a more or less reflected written self-description of the boys' life and the various educational measures and expectations they were confronted with. The letters are also, and perhaps foremost, part of the educational system. They express a cultural practice ${ }^{7}$ that has to be contextualised within the meaning of letter-writing around 1800. In this particular case, letter-writing was part of the educational setting as a way of regular introspection, to confess one's behaviour and report on the weekly learning progress. The dependence on religious or more precisely Protestant or Moravian practices ${ }^{8}$ and language is thus no accident, but an integral part of the educational belief system - and not just Pestalozzi's?.

In the first part of the paper the educational objectives of Pestalozzi's institute are presented with a specific focus on his official and programmatic writings for the institute in Yverdon. It is shown that Pestalozzi's notion of the method the key concept of his education and schooling - was more than just a tool for instruction, for the term stood for an encompassing educational goal. The second part reconstructs the practices of upbringing and schooling as they emerge from the boys' letters. These descriptions will be supplemented by the comments of the Lejeunes' private tutor Mieg, the assessment reports by Pestalozzi's teachers, and the older boy's final reports. The paper will conclude with some remarks on educational objectives and practices in Yverdon, examining among other things the extent to which a child's view or egodocuments transmit a different understanding of educational practices.

\section{Pestalozzi's understanding of upbringing and schooling in Yverdon}

Pestalozzi established his institute in Yverdon for the education of young boys and girls in 1805, after having led similar institutes in Burgdorf and Münchenbuchsee since 1800. The purpose of these institutes was threefold: first, Pestalozzi aimed to test and develop the educational method he had «discovered» around 1800; second, it was a boarding school for the offspring of

7 For the methodological discussions on practice in history and the history of education, see, for example, Theodore R. Schatzki, Karin Knorr-Cetina, Eike von Savigny (eds.), The Practice Turn in Contemporary Theory, London, Routledge, 2001; Lucas Haasis, Constantin Rieske (eds.), Historische Praxeologie, Paderborn, Schöningh, 2015; Andreas Hoffmann-Ocon, Andrea De Vincenti, Norbert Grube (eds.), Praxeologie in der Historischen Bildungsforschung, Bielefeld, transcript, 2020.

$8 \quad$ See, e.g., Sara Aebi, Mädchenerziehung und Mission. Die Töchterpension der Herrnhuter Brüdergemeine in Montmirail im 18. Jahrhundert, Köln, Böhlau, 2016, p. 27-28.

9 See Daniel Tröhler, «The Educationalization of the Modern World. Progress, Passion, and the Protestant Promise of Education", in Paul Smeyers, Marc Depaepe (eds.), Educational Research: The Educationalisation of Social Problems, Dordrecht, Springer, 2008, p. 31-34. 
wealthier families from all over Europe without excluding children of poorer origin. They were often sent to Pestalozzi by their local governments to become rural schoolteachers. And third, it was a place for further education for teachers and teacher trainees, which was - besides his task as private tutor of the Lejeune brothers - also the reason for Mieg's stay in Yverdon ${ }^{10}$. According to Pestalozzi, in the first letter of his famous book How Gertrude teaches her Children (1801), his «discovery» of the method was no accident: since his youth he had been engaged in the reform and improvement of the living conditions of the broad population, be it by agricultural or proto-industrialized enterprises, by the publication of the four-volume novel Leonhard and Gertrud (1781-1787), by advising governments (sometimes, his counselling was only offered, e.g., by Leopold II, Grand Duke of Tuscany), or by his position as the head of an orphanage in Stans after the invasion of French troops in 1798. All these different attempts and experiences brought him - he explains - to the conviction that the improvement of the society can't be left to an enlightened ruler or a revolutionary government but is grounded in a new education, signified by the "method ${ }^{11}$. These promises met the expectations of an era that began to dream of solving political, societal, and social problems through education. Pestalozzi thereby became one of the most effective propagators of the so-called «educationalization of social problems $»^{12}$ and was able to exploit these expectations for his purposes with utmost skill.

Even if Pestalozzi first developed his method for a familial context - the real goal of the method was the comprehensive development of all human abilities in early childhood with the help of mothers - it was soon seen as a tool for school reforms. The educational minister of the Helvetic Republic at the time, Philipp Albert Stapfer, hired Pestalozzi as head of the new national teacher seminar in Burgdorf, as he required a simple and promising method of teaching for the new schools in the revolutionary Helvetic Republic aiming at educating its patriotic future citizens ${ }^{13}$. Stapfer praised Pestalozzi's method as a new, efficient

10 In 1807 , a total of 143 pupils joined the institute, 118 boarders and 25 external students. 82 pupils originated from all over Switzerland, 30 from abroad. They were taught by 9 teachers and 11 teacher-assistants. 9 teachers joined Yverdon to get acquainted with the method and 2 private tutors stayed there for the same reason (Johann Heinrich Pestalozzi, «Bericht an die Eltern und an das Publikum über den gegenwärtigen Zustand und die Einrichtung der Pestalozzischen Anstalt in Iferten, 1808», in Sämtliche Werke, Band 21, Zürich, Orell Füssli, 1964, p. 11-87, here p. 86-87).

11 Johann Heinrich Pestalozzi, «Wie Gertrud ihre Kinder lehrt, ein Versuch den Müttern Anleitung zu geben, ihre Kinder selbst zu unterrichten, in Briefen (1801)», in Sämtliche Werke, Band 13, Berlin, Walter de Gruyter, 1932, p. 181-359, here p. 183-211.

12 Paul Smeyers, Marc Depaepe (eds), Educational Research: the Educationalization of Social Problems, Dordrecht, Springer, 2008; Daniel Tröhler, Pestalozzi and the Educationalization of the World, New York, Palgrave Macmillan, 2013, p. 62-94.

13 The idea to use schooling to educate future citizens was a wide-spread idea around 1800 (see Daniel Tröhler, Thomas S. Popkewitz, David F. Labaree (eds.), Schooling and the Making of Citizens in the Long Nineteenth Century, New York, Routledge, 2011), also in the Prussian government. This 
and easy way to teach reading ${ }^{14}$ and thereby helping to fulfil the educational aspirations of the Helvetic government. It was no problem for Pestalozzi to adjust his notion of the method to the new context and to make obvious why his method - not the only one discussed in educational and pedagogical contexts around $1800^{15}$ - could function as a guideline for the new, «modern s school. Consequently, the Helvetic government ideologically but also financially supported his institute and expected Pestalozzi to develop teaching materials for the new school and to train future teachers.

In 1807, the same year that the Lejeune brothers came to Yverdon, Pestalozzi published a Bericht an die Eltern (Report to Parents) in the official publication of the Pestalozzi institute, the Wochenschrift für Menschenbildung (Weekly Paper for the Cultivation of the Human Being), in which he gave an account of his institution and, at the same time, advertised for new students to join. Thereby he explicitly aimed to present his notion of education and schooling to the parents of his pupils, but also to present his current educational method, his wishes, expectations, and hopes ${ }^{16}$. In the Report, he argued against a broad variety of false opinions of what upbringing and schooling in Yverdon meant: it was neither just a mechanic way of learning ${ }^{17}$ nor an overwhelming of the child's mind, nor a non-religious, or revolutionary, or even Jesuit educa$\operatorname{tion}^{18}$. Nor was it only suitable for young, poor or wealthier children, quite the contrary. Pestalozzi saw the advantage of his institution and the method in being a kind of a holistic education, even if this particular term had not yet come into use. In Pestalozzi's eyes, Yverdon was ruled by «the spirit of a large familial association, in which, given the need, there shone forth everywhere a pure, paternal and brotherly sense». Life in the institute was about «improving the child's

was why it sent so-called Eleven (teacher trainees) to Pestalozzi to get acquainted with Pestalozzi's method (Rebekka Horlacher, «Do educational models impose standardization? Reading Pestalozzi historically», in Thomas S. Popkewitz (ed.), Rethinking the history of education. Transnational perspectives on its questions, methods, and knowledge, New York, Palgrave Macmillan, 2013, p. 135156).

14 Rudolf Luginbühl, Philipp Albert Stapfer, helvetischer Minister der Künste und Wissenschaften (1776-1840): ein Lebens- und Kulturbild, Basel, R. Reich, 1902, p. 187-188.

15 Daniel Tröhler, "Methode" um 1800. Ein Zauberwort als kulturelles Phänomen und die Rolle Pestalozzis», in Daniel Tröhler, Simone Zurbuchen, Jürgen Oelkers (eds.), Der historische Kontext zu Pestalozzis "Methode». Konzepte und Erwartungen im 18. Jahrhundert, Bern, Haupt, 2002, p. 9-30; Barbara Caluori, Rebekka Horlacher, «Bildungsreform als Frage nach der "richtigen" Methode. Das Beispiel des Kantons Neuenburg im ersten Drittel des 19. Jahrhunderts», in Wilfried Göttlicher, Jörg Link, Eva Matthes (eds.), Bildungsreform als Thema der Bildungsgeschichte, Bad Heilbrunn, Klinkhardt, 2018, p. 89-103.

16 J.H. Pestalozzi, Bericht an die Eltern, op. cit., p. 44.

17 Pestalozzi thereby defended his way of schooling especially against the various private boarding schools in French-speaking Switzerland - in particular for girls - where learning the French language was the main goal (S. Aebi, Mädchenerziehung, op. cit., p. 119-120).

J.H. Pestalozzi, Bericht an die Eltern, op. cit., p. 45-46. 
entire disposition and attitude, it is teaching in accordance with nature ... it is a school of familial attachment and familial connection». ${ }^{19}$ The teacher accompanied the students around the clock, took care of them in their free time and, as a rule, also slept in the same rooms as the students ${ }^{20}$. Thus, the students were never without educational supervision. Pestalozzi then went on to describe his facility as a "family-like school», ${ }^{21}$ seeking to make clear that this school was not «merely» a place for transmitting knowledge but rather a combined living- and working-place, where upbringing and teaching were seen as inextricably linked. The teachers gathered regularly to discuss their teaching and the pupil's behaviour, which allowed the educational progress to be constantly observed, evaluated and improved ${ }^{22}$.

After a detailed description of the daily routine in Yverdon, of his religious beliefs - Pestalozzi's education was regularly accused of being areligious - and of the various efforts to keep the children safe and well, Pestalozzi goes on to assert that the core concerns of instruction and upbringing in Yverdon are to use "object teaching" or "object lessons» (Anschauungsunterricht) to help the students, at the start of their education, to «feel and consider, understand and practice their bodily, intellectual, aesthetic, moral, and religious abilities, strengths, and activities ${ }^{23}$. This curriculum was supplemented with learning about human nature and the external world, thereby laying the foundation for all further learning. Along the way, it was important that children "experience things and discover them as a living, organic whole, harmonically interconnected according

19

Ibid., p. 47.

20 Ibid., p. 48.

21 Ibid., p. 49.

22 See also Rapportbuch über die Schüler der Anstalt (1810-1817), Zentralbibliothek Zürich, Ms Pestal 1400.

23 J.H. Pestalozzi, Bericht an die Eltern, op. cit., p. 62-63. The concept of «object teaching» and «object lesson» became important in the English-language discourse about teaching and pedagogy, especially in the United States in the nineteenth century. One of the prominent promoters of this term was Hermann Krusi jun., the son of Pestalozzi's first associate Hermann Krusi, who emigrated to England in 1845 and to the United States in 1852, taught at the Oswego College and published a book about Pestalozzi in 1875. In it, Krusi offers insights into Pestalozzi's life, his writings, his basic ideas and their dissemination in Europe and the United States and ennobled himself as the "true" Pestalozzian fellow by his long experience as school teacher and his memory of «the testimony of many personal friends of Pestalozzi» (Hermann Krusi, Pestalozzi. His life, work, and influence, Cincinnati, Wilson, Hinkle, 1875, p. vii). In a separate chapter, he explains what «object lesson» means according to Pestalozzi. Even if Krusi connects «object teaching» and «object lesson» closely to Pestalozzi's ideas and concepts, the story is more complicated. Like the notion of «Pestalozzian» in the school reform debates of the first half of the nineteenth century, relating «object teaching» or «object lesson» to Pestalozzi was primarily a question of labelling (Rebekka Horlacher, «Best Practice) Around 1800. Johann Heinrich Pestalozzi's Educational Enterprise in Switzerland and the Establishment of Private Pestalozzi Schools Abroad», Encounters on Education 12, 2011, p. 3-17). The concept of «object teaching» was not an invention by Pestalozzi either, he just picked up and successfully - popularised an idea originating in the empiricism of the eighteenth century. 
to necessary and eternal laws, and as such, as a self-presenting and developing whole emerging from something simple and original, and from this experience, to develop an understanding of how each is founded and exists in the other and through the other ${ }^{24}$. Language instruction should also obey this principle. It should aim not only to improve and perfect reading and writing skills, but should be «treated as a ... means for an all-encompassing education of the mind and the heart ${ }^{25}$. Geography, natural history, experimental natural science, history, arithmetic, bookkeeping, and geometry were all taught in keeping with the same principle. This truly diverse curriculum also included drawing and singing, and interested students could obtain an introduction to handicrafts in the city's workshops ${ }^{26}$.

Despite Pestalozzi's emphasis on the harmonious development of the natural abilities in each subject, schooling at Yverdon went beyond elementary level. He was convinced that «the genuine and general elements and the foundation for fostering intellectual abilities are at the same time the general and unchangeable elements and starting points of every science». ${ }^{27}$ To the same extent that the method reinforces a child's abilities, the child's knowledge grows. Moreover, Pestalozzi believed his method would have positive impacts on the «vocational education of the people ${ }^{28}$, as his method would enable students to understand and work independently in their own chosen line of work, since it would awaken the "spirit of industry» ${ }^{29}$. One could summarize the educational curriculum in Yverdon by saying that it offered a sound and comprehensive «cultivation of the individual human being» (Menschenbildung). In his Report, Pestalozzi focussed mainly on the teaching curriculum and the theoretical, philosophical, and psychological embedding of his method as well as the advertisement of a healthy and secure environment. The practice of upbringing and instruction was hardly touched upon. Yverdon was thus positioned as the optimal educational destination for a nascent community of parents valuing education and looking for a socalled modern education ${ }^{30}$.

\footnotetext{
24 J.H. Pestalozzi, Bericht an die Eltern, op. cit., p. 63.

25 Ibid., p. 65.

26 Girls were taught according to a comparable curriculum, however without bookkeeping, drawing and singing but instead with «feminine occupations», ibid., p. 84.

27 Ibid., p. 74.

$28 \quad$ Ibid., p. 75-76.

$29 \quad$ Ibid., p. 76.

30 Rebekka Horlacher, «Private Bildungsangebote, wohlhabende Eltern und die Karriereplanung ihrer Kinder in Pestalozzis Anstalt in Yverdon", Die Lebenswelten Pestalozzis im Spiegel seiner Korrespondenz 1760-1810. Jahrbuch der Schweizerischen Gesellschaft für die Erforschung des 18. Jahrhunderts 1, 2010, p. 133-151.
} 


\section{Schooling and upbringing in the letters of the Lejeune brothers}

In the first letters written by Eduard Lejeune to his parents, there is little about schooling or educational practice. Lejeune spends more time discussing his physical well-being. His detailed and often repetitive descriptions of the state of his body may be related to the fact that he suffered from a skin rash ${ }^{31}$ and his father, as a medical doctor, paid close attention to its treatment. Eduard further discussed his social behaviour in detail, so that his comments about individual courses or leisure time activities occupied a distant third place. This emphasis on different concerns shifted over time during his stay in Yverdon. Discussions of his school activities and subjects increased significantly as his reporting on his health decreased. What remained constant were reports about his behaviour, though their tone changed.

A few weeks after his arrival in August 1807, Eduard already informed his father that he was happy to be in Yverdon, even though at the start, none of his fellow students had liked him; they even «hated» him ${ }^{32}$. As a matter of fact, his behaviour did not appear to have been altogether unproblematic, but it was only half a year later that he reported he was no longer fighting with his friends as frequently as before. He proudly wrote that he had improved his behaviour, experienced a pleasant week, prayed often and with seriousness, in sum, «made progress $»^{33}$. The letters he sent home consistently included self-reflective elements aiming at moral self-improvement. Often he mentions his «carelessness» in the letters, something he was determined to fight against ${ }^{34}$. In response to a parental question about exactly which «bad habits» had led his teachers to complain, Eduard responded, "carelessness, talkativeness, inattention», but he hastened to confirm that he was making progress regarding all three, even if he was

31

This aspect of the letters recalls the child-rearing literature of the eighteenth century, for example, John Locke's Some Thoughts Concerning Education (1693) or the discussions about physical education and later gymnastics as a school subject among the German philanthropists, a group of educators aiming at a modern school and a modern education (see Hanno Schmitt, Vernunft und Menschlichkeit. Studien zur philanthropischen Erziehungsbewegung, Bad Heilbrunn, Klinkhardt, 2007; Jörn Garber (ed.), «Die Stammutter aller guten Schulen». Das Dessauer Philanthropinum und der deutsche Philanthropismus 1774-1793, Tübingen, Max Niemeyer, 2008; Rebekka Horlacher, «The emergence of physical education as a subject for compulsory schooling in the first half of the $19^{\text {th }}$ century. The case of Phokion Heinrich Clias and Adolf Spiess», Nordic Journal of Educational History, Special Issue 4, 2017, p. 13-30).

32 Letter from Eduard Lejeune to his parents, 10 October 1807, Forschungsbibliothek Pestalozzianum Zürich, Autographen-Sammlung, Briefe von Eduard und Gustav Lejeune an ihre Eltern, 18071810, Ms V, 87. Lejeune's letters are published as digitised copies (https://sammlungen.pestalozzia num.ch/korrespondenz-familie-lejeune-teilweise-mit-nachschriften-von-johann-e-mieg-und-vereinzel te-korrespondenz-mit-joseph-schmid-und-pestalozzi-sowie-zeugnisse).

33 Letter, 12 March 1808, Ms V, 100.

34 Letter, 23 October 1809, Ms V, 138.

xviii.ch 12/2021, 89-102, DOI: 10.24894/2673-4419.00117 
«not always true to his intentions» and "sometimes did things» he later regretted. ${ }^{35}$ A year later, his tendency for carelessness had improved somewhat, or at least that is what one reads in his letters. Talkativeness, however, remained a problem ${ }^{36}$.

Eduard's health was an important topic in his own letters, and also in the letters his private tutor wrote to the parents of the Lejeune family, something that becomes especially evident in a long, explanatory addition to a letter from 7 December $1807^{37}$. In this letter, Eduard had let his father know about a recurrent sore throat, an issue that the tutor himself had never mentioned in his correspondence with the parents. This in turn triggered father Lejeune to protest, and the tutor defended himself in detail while also trying to be reassuring: he reported that Eduard had been checked regularly, and that at no time had the sore throat been shown to relate to a dangerous illness. "I want to generally assure you that the moment some accident should happen to your children, I would be the first to let you know about it, and any time you haven't heard from me, you can be sure that nothing has happened to them $»^{38}$.

This quantitative emphasis on information about physical health, moral behaviour, and the school curriculum is still evident some two years after Eduard's arrival at the institute; both in Eduard's and in Mieg's letters. However, Eduard's duty to regularly correspond with his parents became tedious, and Eduard complained that he didn't know what to write when he wasn't responding to concrete questions ${ }^{39}$. For this reason, he asked his teacher, maybe Mieg, to suggest a few questions that he could answer for his parents. Among these ten questions, the first four related once again to his body. For example, he was asked whether he was wearing woolen underwear, whether he still had any remnants of the skin rash, or still had worms ${ }^{40}$. Five additional questions had to do with his curriculum at school and outside of school, and he was specifically asked about instruction in geography, in natural history, and in Latin, whether he had taken up fencing, and if he was diligent in class and satisfied with him-

35 Letter, 18 November 1809, Ms V, 140.

36 Letter, 22 January 1811, Ms V, 188.

37 Even if the tutor was responsible only for the two Lejeune boys, he also reported the behaviour and the well-being of numerous other students from Frankfurt, while Lejeune's father was in charge of communicating the news from Yverdon to the other parents in Frankfurt (e.g., Letter, 13 August 1808, Ms V, 109). Thus the correspondence between the Lejeune brothers and their parents was "more» than a mere family affair; it also served as an exchange between a group of parents - personified by the father Lejeune - and the institute in Yverdon - personified by the tutor/teacher Mieg about a «modern" or "up-to-date» way of schooling in which upbringing played a major role (see also Rebekka Horlacher, "Teachers and Teaching», in Daniel Tröhler (ed.), A Cultural History of Education in the Age of Enlightenment, London, Bloomsbury, 2020, p. 131-145).

38 Letter, 07 December 1807, Ms V, 94.

39 This fact was also mentioned in the tutor's letters. He excuses Eduard's not knowing what to write with hearing his schoolmates playing in the courtyard (Letter, 18 June 1808, Ms V, 105).

40 Letter, 18 November 1809, Ms V, 140. 
self $^{41}$. Lejeune's responses to these educationally framed questions seem quite brief, and either take the very short form of yes- or no-answers or are purely informational. The questions about specific subjects in the curriculum suggest that his parents wanted him to have further instruction, including fencing classes, and except for instruction in geography it was all postponed to a later date, because he was «still too weak», or "[couldn't yet] have so many other classes ${ }^{42}$. A more detailed response is offered to the question regarding his classroom behaviour. Until a few days earlier, he had not been so pleased with his behaviour, «but now I have become more firmly resolved and I already feel I've improved a little» ${ }^{43}$. Thus, at least in reporting an improvement, he was meeting his parents' and his teachers' expectations.

Around a year later, Eduard was given another set of now eleven questions, and apart from three questions about his behaviour these questions now related exclusively to the school curriculum. ${ }^{44}$ In this set once again, the types of questions generally prompted the "correct answers». In contrast, the questions about physical well-being seem to have become irrelevant, and instead, his performance in school subjects had taken on greater importance. He was asked about his «enjoyment of learning», about his mastery of written and spoken French, and his scores on the most recent exams (he was generally pleased with his grades except in Latin). His teachers agreed with this assessment, as Eduard also detailed in his answer to the question as to why he had progressed to the next grade ${ }^{45}$. In response to the question whether he could have «studied more and better over the past year», he limited his answer to just saying "yes». To the question whether he had any weakness he wished to "report», he simply answered «none», although he did mention the by now familiar «inattention" and «talkativeness». His answers give an overall impression of a student's «selfevaluation» about his performance and his behaviour at school. This aspect of the practice of letter-writing became obvious in a letter from 28 June 1811, where Eduard attached a copy of his behaviour book, ${ }^{46}$ reporting a detailed daily

41 One question also related to private classes with Ms. Hoffmann, but it is unclear what kind of classes were involved.

42 Letter, 18 November 1809, Ms V, 140.

$43 \quad$ Ibid.

44 Letter, 22 January $1811, \mathrm{Ms} \mathrm{V}, 188$.

45 In these times, grades were not organised according to the age of the pupils but by their level of knowledge. When the learning objectives of a grade were reached, the student progressed to the next grade. Dividing students into grades thus replaced step by step the collective private teaching in the classroom. This traditional pedagogy meant that the teacher interrogated one student after another, while all other students were idle.

46 Keeping a behaviour book was recommended to Eduard by Johannes Niederer, teacher for religion and one of the prominent associates of Pestalozzi's institute. Whether keeping a behaviour book was a widespread practice in Yverdon or whether only Eduard kept such a book is unclear. However, it can be assumed that it was a common practice since introspection was part of education. 
timetable completed with the teacher's comments on his behaviour for almost every single lesson. ${ }^{47}$

Monday 10 June 1811. 6-7 Jordan ${ }^{48}$ good, keep it up 8-9 Blochmann ${ }^{49}$ silent and attentive 9-10 Baumgarten ${ }^{50}$ good 10-11 work in silence 11-12 Brousson ${ }^{51}$ very good $1^{1 / 2}-2^{1 / 1} / 2$ work in silence $2^{1 / 2}-3^{1 / 2}$ Blochmann satisfied 5-6 Hofmann ${ }^{52}$ satisfied 6-7 and 7-8 cleaning the shotguns.

Tuesday 11 June 1811. 5-6 Schacht ${ }^{53}$ silent 6-7 Niederer ${ }^{54}$ does not prepare templates 8-9 Göldy ${ }^{55}$ satisfied 9-10 Göldi satisfied 10-11 Brousson very good. I did not list the rest of the day, because it was review and military exercising

Wednesday 12 June 1811. 5-6 and 6-7 slept 8-9 Baumgarten good 9-10 Göldi not reported 10-11 Brousson very good 11-12 Göldi not reported 1 1/2-2 $1 \frac{1}{2}$ Blochmann attentive $2^{1} \frac{1}{2}-3^{1} / 2$ worked independently $4-5$ Schacht silent $5-6$ quite diligent

Thursday 13 June 1811. 5-6 Jordan good 6-7 Schacht silent 8-9 Baumgarten wellbehaved 9-10 Göldi satisfied 10-11 Brousson very good 11-12 work in silence $1 \frac{11}{2}-$ $2^{1} \frac{1}{2}$ Blochmann good $2^{1} / 2-3^{1} / 2$ Göldi not attentive enough 4-5 Schacht satisfied 5-6 Schacht did not learn his lesson well enough ${ }^{56}$.

In the above-mentioned reply by Eduard, written after around three years at the institute, he first raised the issue of returning to Frankfurt. Although Eduard had occasionally suggested in earlier letters that he missed his parents and his hometown, in this letter, he specifically wonders whether he would be coming back home in the summer or should spend another year in Yverdon. A short time later, he went on to list three concrete reasons favouring his return to Frankfurt. First, he says he has heard from his private tutor that there were now schools in Frankfurt that were just as good as the one in Yverdon. Second, he has been abroad for such a long time and he sometimes yearns to return home, and third, he argues, staying at home would be less expensive ${ }^{57}$. Thus, one of the main reasons for choosing Yverdon had been the presumed quality of schooling, not available in Frankfurt at that time, even if in the letters questions of upbringing and health had been discussed in particular; questions - from today's point of view - not necessarily associated with the quality of schooling.

47 See also the letter from 23 July 1811 (Ms V, 223).

48 Mathematics teacher.

49 Teacher for religion, German language, geography, music.

50 Assistant teacher for mathematics.

51 Latin teacher.

52 Teacher for philosophy and rhetoric.

53 German, history and Latin teacher.

54 Teacher for religion.

55 Mathematics teacher.

56 Letter, 28 June 1811, Ms V, 224.

57 Letter, 4 February 1811, Ms V, 214. 
Thus, teaching and other school activities in Yverdon reveal a "familylike», that is, "homelike» school. The aim was not only to provide a modern school curriculum and thereby position the school to serve the rising bourgeois class, but instead, the emphasis was quite deliberately on education as a moral exercise, which became very obvious in Eduard's letters. Pestalozzi explicitly argued for this kind of upbringing and schooling in his programmatic texts, where he spoke about «attitude development», fostering talents and strengths, and learning through observation. These fundamental educational principles were also apparent in the final reports issued to Eduard by his teachers when he left Yverdon in August 1811. For example, the French teacher Julien Lehmann did not comment on Eduard's command of French, but instead exclusively on his social behaviour, his intellectual abilities, and his commitment. He stressed that Eduard required «rigorous encouragement to work», that he had "no initiative», and for this reason his performance was "deficient and unsatisfactory», not because of a lack of «intellectual capacity» but rather because of a lack of "assertiveness and a sense of responsibility». His irritability needed to be «tempered», and he ought to be held to «a definite life plan» in order to «bring order to his way of life», as otherwise one could fear that the «inconsistency of his external life might impact his internal life», which in turn would lead to «his abilities and talents» to develop in "a skewed direction». ${ }^{88}$ His former geography teacher and now teacher of religion, Johann Wilhelm Mathias Henning, also expressed a negative opinion about Eduard's character. He lacked «sense» and «spirit» and overall, he was «superficial and frivolous» ${ }^{59}$. The only positive assessments came from the teachers of geometry, Fridolin Baumgartner, and drawing, Johannes Ramsauer. Especially in arithmetics, Eduard seems to have met his teacher's expectations, and his behaviour in these classes was never a cause of complaint, even though once again, there was mention of his talkativeness and inattention ${ }^{60}$.

\section{Egodocuments as a specific view on upbringing and schooling?}

The sources I have examined in this paper reflect the great importance assigned to moral education, proper behaviour, obedience, concentration, and attention in Pestalozzi's institute. They depict Yverdon as a boarding school where upbringing and schooling were thought of as one, that is it was a place where upbringing was the underpinning and superstructure of teaching and instruction. In this context, letters to the parents were more than a mere means of com- 
munication but rather a practice to supervise and monitor the education that was offered; for this reason, the brothers were required to report about their daily life. In turn, their father asked detailed questions when he thought he was being insufficiently informed, and especially expected that his son's personal tutor keep him apprised about all important events in order that he, as the father, could make educational interventions if necessary.

Thus, and according to the brothers' letters, daily life in Yverdon met the requirements of Pestalozzi's education concept, which he had effectively described to his public as a "method». The Lejeune brothers' letters show that the concept of the method was not merely a theoretical consideration or a unique selling point; rather, it seems that it closely shaped educational practice. The emphasis on social behaviour and inner attitude, surpassing the importance of the curriculum - at least in the first years of the brothers' stay in Yverdon - are most obvious in the sources. In spite of (or perhaps due to) the fact that Yverdon was chosen because of the quality of the school, education in Yverdon was not primarily instruction in specific subjects, but education and practice in social and moral behaviour ${ }^{61}$. And while Pestalozzi's method indeed became a shining light of the educational profession in the nineteenth century ${ }^{62}$, public schools, for which Yverdon, according to Pestalozzi's own view, was meant to be a model, developed largely independently of his educational and pedagogical offerings ${ }^{63}$.

However, these divergences are not a topic in the Lejeune brothers' letters. Thus, the child's view of Yverdon depicted in these letters certainly does open up insights into the practices in Yverdon, e.g., the use of behaviour books, but nevertheless maintains a particular perspective on a historical phenomenon. And that's why egodocuments, like any other historical documents, only become meaningful through historical contextualisation. Egodocuments are therefore neither better nor worse sources, they are just one (albeit an important one) among a broad variety of possibilities, helping us to reconstruct a specific past. And as any documents, they don't talk themselves but must be questioned, analysed and contextualised to show their meaning. Thereby the crucial analysis

61 This point caused irritation with several parents, as they expected from Yverdon first and foremost successful learning and desirable conduct, not a long-term development of individual strengths (see Rebekka Horlacher, "Vocational and Liberal Education in Pestalozzi's Educational Theory», Pedagogía y Saberes 50, 2019, p. 109-120).

62 D. Tröhler, Pestalozzi, op. cit., p. 129-143.

63 Pestalozzi tried to force first the Helvetic government and then the Federal Diet of Switzerland to approve his method as suitable for public schooling, but without success (see Johann Ith, Über die Pestalozzische Lehranstalt in Burgdorf, Bern, [s.n.], 1802; Abel Merian, Gregor Girard, Friedrich Trechsel, Bericht über Pestalozzis Erziehungs-Anstalt zu Yverdon, an Seine Excellenz den Herrn Landammann und die Hohe Tagsatzung der Schweizerischen Eidgenossenschaft, Bern, Ludwig Albrecht Haller, 1810; Danièle Tosato-Rigo, Sylvie Moret-Petrini «Généraliser la méthode Pestalozzi? Une évaluation en Suisse romande et son horizon d'attentes (1806)», Die Lebenswelten Pestalozzis im Spiegel seiner Korrespondenz 1760-1810. Jahrbuch der Schweizerischen Gesellschaft für die Erforschung des 18. Jahrhunderts 1, 2010, p. 108-132). 
includes the combination of secondary texts, research question and sources, regardless if they are egodocuments or not. But if they are available and contextualised, they in fact offer an additional perspective on the past, be it educational or other. And above all, they enable the reconstruction of practices, thus adding a material dimension to our history of the past.

Dr. Rebekka Horlacher, University of Zurich, Institute of Education, Freiestrasse 36, 8032 Zurich, rhorlach@ife.uzh.ch 